\title{
Impact of Intellectual Capital on the Organizational Performance of Islamic Banking Sector in Malaysia
}

\author{
Dr. Muhammad Khalique \\ Department of Business Management, Universiti Malaysia Sarawak, Malaysia \\ E-mail: drmkhalique@gmail.com \\ Dr. Jamal Abdul Nassir bin Shaari \\ Department of Business Management, Universiti Malaysia Sarawak, Malaysia \\ E-mail: jamalnassir@yahoo.com
}

Prof. Dr. Abu Hassan bin Md. Isa

Department of Accounting and Finance, Universiti Malaysia Sarawak, Malaysia

E-mail: miahassan@feb.unimas.my

Noridah Binti Samad

Universiti Malaysia Sarawak, Malaysia

Received: July 14, 2013 Accepted: September 11, 2013 Published: December 1, 2013

doi:10.5296/ajfa.v5i2.4005 URL: http://dx.doi.org/10.5296/ajfa.v5i2.4005

\begin{abstract}
In a contemporary business environment, intellectual capital is considered as the most critical strategic asset for the success of the organization. Intellectual capital is a life blood of the high-tech and knowledge intensive organizations. Banking sector is considered as a knowledge intensive segment. Therefore, there is a great need to nourish the concept and applications of intellectual capital in banking sector. In Malaysia, banking sector is mainly based on conventional banking sector and Islamic banking sector. This study was conducted on Islamic banking sector operating in Kula lumpur Malaysia. A total of 120 individuals were
\end{abstract}




\section{Macrothink}

Asian Journal of Finance \& Accounting ISSN 1946-052X 2013, Vol. 5, No. 2

participated in this study to examine the influence of intellectual capital on the organizational performance of Islamic banking sector. Pearson correlation and multiple regression analysis were used to determine the influence of intellectual capital on the performance of Islamic banking sector. The results revealed that intellectual capital has significant influence on the performance of Islamic banking sector in Malaysia.

Keywords: Intellectual capital, Human capital, Customer capital, Structural capital, Performance 


\section{Introduction}

In a knowledge-based economy, intellectual capital has secured overwhelming attention from the researchers, academicians, practitioners and entrepreneurs. Many researchers such as (Ahmad Sharabati, Ibrahim Nour, \& Sajid Shamari, 2013; Bataineh \& Al Zoabi, 2011; Bontis, Keow, \& Richardson, 2000; de Castro \& Sáez, 2008; de Pablos, 2003; Ismail, 2005; Khalique, 2012; Khalique, Shaari, Isa, \& Alkali, 2012; Ordonez de Pablos, 2004) have found that intellectual capital is appeared as the most vital asset for the success of organizations. They argued that intellectual capital is based on the soft assets or intangible assets of the organizations that will help to organizations to create value added products and services. Fundamentally, intellectual capital performs a crucial rule to enhance the innovation and creativities in organizations. In an organization intellectual capital is used to create value addition features in their products and services. In competitive environment high-tech industries or knowledge based organizations mainly based on the knowledge assets which refer to intellectual capital. Banking sector is considered as the knowledge intensive sector, and this sector mostly offers services orientated products to their customers.

Presently, banking sector plays a crucial role for development and growth of the national economy. Banking sector performs as a lever to facilitate the financial transactions. Competitive environment and globalization business challenges has forced to organizations to reshape into knowledge intensive organizations rather than traditional. When knowledge-intensive organizations tend to dominate in the competitive finance sector, there is a need to capitalize the organizational resources, especially intellectual capital. Like other countries, in Malaysia the banking sector is playing vital role for the development and growth of economy. It can also consider as the banking sector is a back of bone of economy, particularly in present time banking sector involve in every segment of our life. Malaysian banking sector is based on Conventional and Islamic Banking Sector. In Malaysia, these both sectors are performing on parallel lines and their significant positive contribution in the development of economics is highly recognized by the government. In previous studies, researchers mainly focused on Conventional Banking Sector while the Islamic Banking Sector got insignificant attention from the researchers, therefore, in this study, the researchers focused on Islamic Banking Sector to examine the role of intellectual capital in order to enhance the organizational performance.

There is no doubt that there are many other important factors that contribute to enhance the performance of organizations but in a knowledge-based economy, many researchers such as (Bataineh \& Al Zoabi, 2011; Bontis et al., 2000; Bueno, Salmador, \& Rodríguez, 2004; Díez, Ochoa, Prieto, \& Santidrián, 2010; Khalique, 2012; Khalique, Shaari, \& Isa, 2011; Ordonez de Pablos, 2004) have found that intellectual capital is one of the most important and strategic assets for the success of organizations. They argued that in a competitive business environment intellectual capital is considered as the life blood of knowledge intensive organizations. In addition, they emphasis that it is indispensible for high-tech industries such as (service oriented and manufacturing orientated) to generate and capitalize their intellectual capital in order to get the competitive edge in cutthroat competition. 


\section{Intellectual Capital}

Intellectual capital is manly based on the soft assets of the organizations that contribute to enhance the performance of the organization. In a knowledge-based economy, the nature of resources has been changed. In agriculture-based economy and industrial-based economy the organizations mainly based on tangible assets but now in a knowledge-based economy, intangible assets are considered as the vital resources for the success of organizations. Intellectual capital is considered as the nucleus of a knowledge-based economy. The term intellectual capital was first introduced by John Kenneth Galbraith in 1969 (Feiwal, 1975). He understood that intellectual capital meant more than just "intellect as pure intellect" but rather incorporated a degree of "intellectual action". Intellectual capital is based on intangible assets. Due to the vital contribution in the innovation, development, growth and enhancement of the organizational performance intellectual capital has secured overwhelming responses from the researchers. To understand intellectual capital in depth many researchers divided intellectual capital into different components for example (Stewart, 1997) argued that intellectual capital is based on three components namely, human capital, customer capital and structural capital. Intellectual capital model of McElroy is based on human capital, structural capital and social capital (McElroy, 2002). Ismail argued that intellectual capital is based on human capital, customer capital, structural capital and spiritual capital (Ismail, 2005). In 2006 (Bueno, Salmador, Rodríguez, \& De Castro, 2006) argued that intellectual capital is encompasses on human capital, organizational capital/structural capital, technological capital, social capital and business capital/customer capital. To overcome the scattered opinion about the concept and applications of intellectual capital (Khalique, Shaari, \& Isa, 2011b) proposed integrated intellectual capital model (IICM). The IICM model is based on the human capital, customer capital, structural capital, social capital, technological capital and spiritual capital. However, this study is at preliminary stage therefore, the researchers used only three components namely human capital, customer capital and structural capital.

Human capital is considered as the lifeblood of the organization and it is the crucial source of innovation and development in the organization. Human capital cannot be owned by organization but it can only be rented. Human capital refers employees who work for the success of the organization. The ingredients of capital are mainly, knowledge, skills, expertise, training and development. Customer capital is refers to the customer satisfaction, customer loyalty to the organization while structural capital represent the database, policies, procedures and operating rules of the organizations.

\section{Conceptual Framework}

Figure 1 represents the proposed conceptual framework of this study. This framework posits that there is a direct and positive relationship between intellectual capital and the organizational performance. Four research hypotheses of this research are as follows: 


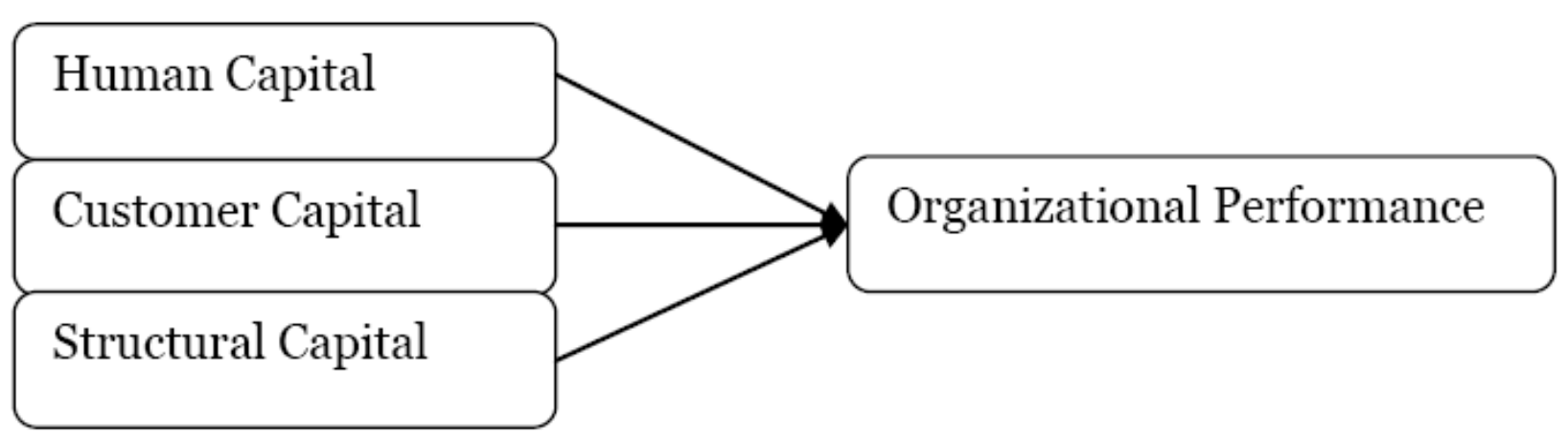

Figure 1. Conceptual Framework

Hypothesis \# 1 Human capital has significant positive relationship with the organizational performance of Islamic banks in Malaysia.

Hypothesis \# 2 Customer capital has significant positive relationship with the organizational performance of Islamic banks in Malaysia.

Hypothesis \# 3 Structural capital has significant positive relationship with the organizational performance of Islamic banks in Malaysia.

Hypothesis \# 4 Intellectual capital has significant positive influence on the organizational performance of Islamic banks in Malaysia.

\section{Research Methodology}

In this study, three components of intellectual capital namely, human capital, customer capital and structural capital are considered as independent variables while organizational performance is used as a dependent variable. To gather the required data 140 applicants were approached from four Islamic bank's headquarters in Kuala Lumpur. The participants were picked through convenience sampling technique. The five point Likert scale research instrument was adopted from (Khalique, 2012). A total of 120 individuals were participated in this study in order to understand the concept and applications of intellectual capital to enhance the organizational performance.

\section{Reliability of Instrument}

Reliability analysis (Cronbach's Alpha) is used to examine the reliability and internal consistency of each individual item. The item loadings obtained 0.6 can be considered as reliable and acceptable (Sekaran, 1992). As demonstrated in Table 1, internal consistency values for each of the four constructs is fine since the alpha values for each are greater than 0.90 . 
Table 1. Findings of the Reliability Test

\begin{tabular}{lll}
\hline Variable & Items & Cronbach Alpha \\
\hline Human Capital & 9 & 0.945 \\
Customer Capital & 8 & 0.920 \\
Structural Capital & 8 & 0.911 \\
Organizational Performance & 10 & 0.912 \\
\hline
\end{tabular}

\section{Testing of Research Hypotheses}

Pearson correlation and multiple regression were used to test the proposed research hypotheses of this study. In this research, correlation and multiple regression are widely used to examine the relationship and influence of independent variables on the dependent variable. Therefore, these two techniques were used to examine the research hypotheses. Table 2 showed that the correlation between the employed components of intellectual capital and organizational performance were significant positive at the $p=0.01$ level (2-tailed). Results illustrated that there is a significant positive relationship between human capital and organizational performance $(r=0.714, p<0.01)$, customer capital and organizational performance $(r=0.727, p<0.01)$ and structural capital and organizational performance $(r=$ 0.659, $p<0.01$ ). In addition, during further analysis it was observed that the customer capital has the strongest relationship with organizational performance of Islamic Banks, followed by human capital, and finally, structural capital.

Table 2. Pearson Correlation between the Independent Variable and Dependent Variable

\begin{tabular}{llll}
\hline Variables & HC & CC & SC \\
\hline Human Capital (HC) & & & \\
Customer Capital (CC) & 0.794 & & \\
Structural Capital (SC) & 0.657 & 0.664 & 0.659 \\
Organizational Performance & 0.714 & 0.727 & \\
\hline
\end{tabular}

Note: Correlation is significant at the 0.01 level (2-tailed) 
Multiple regression was used to test the fourth research hypothesis of this study. The coefficient of determination $\left(R^{2}\right)$ indicates the goodness of fit for the regression model (Namvar, Safaralizadeh, Baniameri, Pourmirza, \& Karimzadeh, 2012). Findings shows that the coefficient of determination $\left(R^{2}=0.611\right)$ of the variance in the organizational performance of the Islamic banks is jointly explained by the employed three independent variables $(F=60.733$; Sig. $=0.001)$. The $R^{2}$ indicated that $611 \%$ of the variance in Islamic bank's performance was explained by the contributions of human capital, customer capital and structural capital. The researchers can conclude that the regression model meets the criteria of goodness of fits to validate the regression model and the fourth research hypothesis also supported. Table 3 depicts the regression model.

Table 3. Multiple Regression Model Summary and Coefficients

\begin{tabular}{|c|c|c|c|c|}
\hline \multirow[t]{2}{*}{ Model } & $\begin{array}{l}\text { Unstandardized } \\
\text { Coefficients }\end{array}$ & $\begin{array}{l}\text { Standardized } \\
\text { Coefficients }\end{array}$ & \multirow[t]{2}{*}{$\mathrm{t}$} & \multirow[t]{2}{*}{ Sig. } \\
\hline & B & Beta $(\beta)$ & & \\
\hline (Constant) & 1.007 & & 3.690 & .000 \\
\hline Human Capital & 0.238 & 0.283 & 2.840 & .005 \\
\hline Customer Capital & 0.303 & 0.336 & 3.357 & .001 \\
\hline Structural Capital & 0.243 & 0.250 & 3.096 & .002 \\
\hline \multicolumn{5}{|l|}{$R=(0.781)$} \\
\hline \multicolumn{5}{|l|}{$R^{2}=(0.611)$} \\
\hline \multicolumn{5}{|l|}{$\operatorname{Adj} . R^{2}=(0.601)$} \\
\hline$F=(60.733)$ & & & & 0.001 \\
\hline
\end{tabular}

Regression-coefficient indicates the degree of each explanatory variables contribution to the variation explained in the dependent variable. All the three variables namely, human capital $(\beta=0.283, p=0.005)$, customer capital $(\beta=0.336, p=0.001)$ and structural capital $(\beta=$ $0.250, p=0.002$ ) were found to be significant predictors at the significant level of $5 \%$. The results showed that all three components of intellectual capital are significantly contributing to enhance the performance of Islamic Banks in Malaysia. 


\section{Discussion, Recommendations and Future Studies}

The findings of this study revealed that the organizational performance of Islamic Banks in Malaysia is influenced by intellectual capital. The findings of this study also supported with the previous studies such as (Abdullah \& Sofian, 2012; Ahmad Sharabati et al., 2013; Bontis et al., 2000; Castro \& Delgado-Verde, 2012; Díez et al., 2010; Khalique, 2012; Khalique et al., 2011; Ngah \& Ibrahim, 2009; Sharabati, Jawad, \& Bontis, 2010). The findings of this study could be encouraged to the concerned authorities to explore and capitalize their intangible assets to enhance the performance of Islamic Banks operating in Malaysia. This study will be a millstone for the potential researchers to conduct their research in high-tech or knowledge intensive industries operating in manufacture and services sector. This study will motivate to the researchers to apply the integrated intellectual capital model (IICM) in their studies to test the IICM model in different sectors of industries and countries.

\section{References}

Abdullah, D. F., \& Sofian, S. (2012). The Relationship between Intellectual Capital and Corporate Performance. Procedia-Social and Behavioral Sciences, 40, 537-541. http://dx.doi.org/10.1016/j.sbspro.2012.03.227

Ahmad Sharabati, A.-A., Ibrahim Nour, A.-N., \& Sajid Shamari, N. (2013). The Impact of Intellectual Capital on Jordanian Telecommunication Companies' Business Performance. American Academic \& Scholarly Research Journal (AASRJ), 5(3).

Bataineh, M. T., \& Al Zoabi, M. (2011). The effect of intellectual capital on organizational competitive advantage: Jordanian Commercial Banks (Irbid District) An empirical study. International Bulletin of Business Administration(10), 15-24.

Bontis, N., Keow, W. C. C., \& Richardson, S. (2000). Intellectual capital and business performance in Malaysian industries. Journal of Intellectual Capital, 1(1), 85-100. http://dx.doi.org/10.1108/14691930010324188

Bueno, E., Salmador, M. P., \& Rodríguez, Ó. (2004). The role of social capital in today's economy: Empirical evidence and proposal of a new model of intellectual capital. Journal of Intellectual Capital, 5(4), 556-574. http://dx.doi.org/10.1108/14691930410567013

Bueno, E., Salmador, M. P., Rodríguez, Ó., \& De Castro, G. M. (2006). Internal logic of intellectual capital: a biological approach. Journal of Intellectual Capital, 7(3), 394-405. http://dx.doi.org/10.1108/14691930610681474

Castro, G. M. D., \& Delgado-Verde, M. (2012). Assessing Knowledge Assets in Technology-Intensive Firms: Proposing a Model of Intellectual Capital. Journal of CENTRUM Cathedra, 1(5), 43-59. http://dx.doi.org/10.7835/jcc-berj-2012-0066

de Castro, G. M., \& Sáez, P. L. (2008). Intellectual capital in high-tech firms: The case of Spain. Journal of Intellectual Capital, 9(1), 25-36. http://dx.doi.org/10.1108/14691930810845786

de Pablos, P. O. (2003). Intellectual capital reporting in Spain: a comparative view. Journal of Intellectual Capital, 4(1), 61-81. http://dx.doi.org/10.1108/14691930310455397 
Díez, J. M., Ochoa, M. L., Prieto, M. B., \& Santidrián, A. (2010). Intellectual capital and value creation in Spanish firms. Journal of Intellectual Capital, 11(3), 348-367. http://dx.doi.org/10.1108/14691931011064581

Feiwal, G. R. (1975). The Intellectual Capital of Michal Kalecki: A Study in Economic Theory and Policy. Knoxville, TN.: The University of Tennessee Press.

Ismail, M. B. (2005). The Influence of Intellectual Capital on the Performance of Telekom Malaysia. PhD Thesis, Universiti Teknologi Malaysia.

Khalique, M. (2012). Impact of Intellectual Capital on the Organizational Performance of Selected Small and Medium Enterprises in Malaysia and Pakistan PhD Thesis, Universiti Malaysia Sarawak.

Khalique, M., Shaari, J. A. N., \& Isa, A. H. B. M. (2011). Relationship of intellectual capital with the organizational performance of commercial banks in Islamabad, Pakistan. Paper presented at the 3rd SAICON: International Conference on Management, Business Ethics and Economics (ICMBEE), Pearl Continental Hotel, Lahore-Pakistan.

Khalique, M., Shaari, J. A. N., \& Isa, A. H. B. M. (2011b). Intellectual Capital and its Major Components. International Journal of Current Research, 3(6), 343-347.

Khalique, M., Shaari, J. A. N., Isa, A. H. B. M., \& Alkali, M. (2012). Intellectual capital and banking sector of Pakistan. International Journal of Research in Commerce, Economics \& Management, 2(6), 1-5.

McElroy, M. W. (2002). Social innovation capital. Journal of Intellectual Capital, 3(1), 30-39. http://dx.doi.org/10.1108/14691930210412827

Namvar, P., Safaralizadeh, M. H., Baniameri, V., Pourmirza, A. A., \& Karimzadeh, J. (2012). Estimation of larval density of Liriomyza sativae Blanchard (Diptera: Agromyzidae) in cucumber greenhouses using fixed precision sequential sampling plans. African Journal of Biotechnology, 11(9), 2381-2388.

Ngah, R., \& Ibrahim, A. R. (2009). The relationship of intellectual capital, innovation and organizational performance: a preliminary study in Malaysian SMEs. International Journal of Management Innovation Systems, 1(1), 1-13.

Ordonez de Pablos, P. (2004). The importance of relational capital in service industry: the case of the Spanish banking sector. International Journal of Learning and Intellectual Capital, 1(4), 431-440. http://dx.doi.org/10.1504/IJLIC.2004.005993

Sekaran, U. (1992). Research Methods for Business: A Skill Buiding Approach, John Wiley. New York.

Sharabati, A. A. A., Jawad, S. N., \& Bontis, N. (2010). Intellectual capital and business performance in the pharmaceutical sector of Jordan. Management decision, 48(1), 105-131. http://dx.doi.org/10.1108/00251741011014481

Stewart, T. (1997). Intellectual Capital: The New Wealth of Organizations. New York: Bantam Doubleday Dell. 